\title{
Livoneca sinuata (Crustacea; Isopoda; Cymothoidae) on Loligo vulgaris from Turkey, and unusual cymothoid associations
}

\author{
Jean-Paul Trilles ${ }^{1, *}$, Ahmet Öktener ${ }^{2}$ \\ ${ }^{1}$ UMR 5171 (Génome, Populations, Interactions, Adaptation), Equipe Adaptation Écophysiologique et Ontogenèse, \\ Université de Montpellier 2, CC. 092, Place E. Bataillon, 34095 Montpellier Cedex 05, France \\ ${ }^{2}$ Cihannüma mahallesi Hüsnü savman sok no: 22/5 80690 Besiktas, Istanbul, Turkey
}

\begin{abstract}
In this paper, an unusual association of Livoneca sinuata (Crustacea; Isopoda; Cymothoidae) with the cephalopod Loligo vulgaris is reported for the first time from the Aegean sea coasts of Turkey. Moreover, a review of all the cases of unusual associations involving cymothoids is performed.
\end{abstract}

KEY WORDS: Cymothoidae $\cdot$ Isopod $\cdot$ Unusual associations $\cdot$ Livoneca $\cdot$ Loligo $\cdot$ Turkey

\section{INTRODUCTION}

Cymothoids (Crustacea, Isopoda) typically infect marine, freshwater or brackish water teleost fish. Elasmobranchs have occasionally been reported as hosts for some species, but these data are probably due to trawl transfers (Brusca 1981, Trilles 1994). Some specimens have also occasionally been collected (always only 1 individual) from cephalopods, in their mantle cavity and on their body surface (Hochberg 1990, Trilles 1994). For example: Aegathoa loliginea, now synonymous with Aegathoa oculata (Say, 1818), from the mouth of a squid, Heterololigo (= Loligo) pealei, in Savin Rock, near New Haven, Connecticut by Harger (1878); Nerocila maculata Edwards, 1840 from 'Calamars (Loligo)' in Catalogne (the Mediterranean) by Gibert i Olivé (1919-1920); Nerocila orbignyi (GuérinMéneville, 1829-1832) from an unidentified species of Loligo off the coast of Argentina by Szidat (1955); Codonophilus (Meinertia) sp. settled in the neck of Sepia elegans, from Port Vendres (Pyrénées Orientales, France) by Dollfus (1958); Anilocra carpentariensis n. sp. from Loligo sp. in the Pacific and Indian Oceans by Avdeev (1977); Livoneca sinuata Koelbel, 1878, from the mouth cavity of Sepiola ligulata Naef, 1912 in the Adriatic by Bello \& Mariniello (1998). In addition, Hochberg (1990) noted as unpublished a single individual of an unidentified isopod recovered from Abraliopsis felis in the North Pacific and, quoting Hanlon \& Forsythe, another attached toward the distal end of the mouth of a mature male Sepioteuthis lessoniana.

In this study, we report the occurrence of several specimens (female and male) of the species Livoneca sinuata Koelbel, 1878, in the mantle cavity of Loligo vulgaris Lamarck, 1798. We also review all the cases of unusual cymothoid associations.

\section{MATERIALS AND METHODS}

The samples of Loligo vulgaris, given as feed to mature sea bass Dicentrarchus labrax (L., 1758), were obtained in 2003 from Egemar Aquatic Products (Aydin). Several parasites were collected from the mantle cavity of these cephalopods before disinfectant treatment with clorak. The specimens of Cymothoidae were preserved in $70 \%$ alcohol and measured using a micrometer. The data related to parasites were recorded on parasite cards. The restricted synonymy and some information about the geographic range and host preferences are provided, adapted mainly from 
Trilles (1994). The taxonomic position and the morphometric characteristics of the isopods were determined according to Schioedte \& Meinert (1884), Trilles (1976) and Bello \& Mariniello (1998).

\section{RESULTS}

\section{Livoneca sinuata Koelbel, 1878}

Synonymy:

? Livoneca mediterranea Heller, 1868; Koelbel, 1878; Schioedte et Meinert, 1884; Brian, 1912; Montalenti, 1948; Bruce, 1990.

Livoneca sinuata Koelbel, 1878; Schioedte \& Meinert, 1884; Carus, 1885; Gerstaecker, 1901; Richardson, 1910; Nierstrasz, 1915; Galati-Mosella, 1920; Brian, 1912; Penso, 1939; Montalenti, 1948; Vasiliu and Carausu, 1948; Trilles, 1962, 1968; Boscolo, 1970, 1977; Bruce, 1990.

Cymothoa carryensis Gourret, 1891.

Lironeca sinuata Brian and Dartevelle, 1949; Trilles and Raibaut, 1973; Trilles, 1977; Rokicki, 1984; Trilles, Radujkovic and Romestand, 1989; Bello and Mariniello, 1998.

Not Livoneca sinuata Brian, 1912; Monod, 1924; Vasiliu, 1932; Borcea, 1933; Trilles, 1976.

Material examined. One female (length $=16 \mathrm{~mm}$ ) and 4 males (length $=8,8,8$ and $9 \mathrm{~mm}$ ) were collected in the mantle cavity of 2 Loligo vulgaris among the 24 specimens observed; Prevalence $=8.3 \%$; Intensity min. to max. $=1$ to 4 .

Distribution. Livoneca sinuata has been found in the Mediterranean (Sicily, Gulf of Naples, Sea of Sciacca and Palerme, Sète, Gulfs of the Lion and Marseilles, Tunis Gulf, Zembra, Bou Haroun, Algiers, Montenegro, Adriatic) and the Atlantic (2 km north of Punta Aguruncho, Isla de Arosa, Ria de Arosa, NW coast of Spain; NW Africa) (Trilles 1994). Recently, it has also been collected from a cephalopod host caught in the southwestern Adriatic Sea, off Manfredonia (Apulia, Italy), by Bello \& Mariniello (1998).

Hosts. Livoneca sinuata has been found on Cepola macrophthalma (= C. rubescens), Raja miraletus, Boops boops, Gobius sp. (Trilles 1994) and, more recently, on Brama brama, Trichiurus lepturus, Lepidopus caudatus and Sepiola ligulata (Bello \& Mariniello 1998).

Comments. This is the fourth case of a cymothoid being found on a cephalopod in the Mediterranean. However, it is the first record of Livoneca sinuata from the sea coasts of Turkey, and also of an association with Loligo vulgaris and with several cymothoid individu- als, both male and female. In contrast, many hundreds of sepiolid mantle cavities were examined by Bello \& Mariniello (1998); only 1 isopod was collected and the prevalence, not specified by the authors, was comparatively very low. Lastly, we did not see any significant change in the mantle of the host, similar to that reported for Sepiola ligulata. Bello \& Mariniello (1998) observed that the mantle of this squid was rotated about $110^{\circ}$ along the longitudinal body axis with respect to the head-arms complex, probably caused by the presence of the parasite.

\section{Review of all cases (excluding cephalopods) of unusual cymothoid associations}

Cymothoids are isopod crustaceans which typically infect osteichthyan fish. In addition to the cephalopods already mentioned, they have occasionally been found on several other organisms such as sponges, jellyfish, crustaceans, chondrichthyans, amphibians and humans.

Sponges. A juvenile (species unknown) was reported by Monod (1933) 'dans un spongiaire', from Stn XVI, Gulf of Suez.

A gravid female of Ceratothoa oxyrrhynchaena (Koelbel, 1878) was collected from a sponge from Stn XL, Gulf of Suez, by R. P. Dollfus (Trilles 1972).

Jellyfish. Haswell (1880) found Ceratothoa imbricata (Fabricius, 1775) (as Codonophilus argus sp. nov.) under the bell of a Rhizostoma in Port Jackson, Australian coast.

Aegathoa macrophthalma Dana, 1853 was collected by Boone (1935) from jellyfish from Muntok, Banka Island, Banka straits, Dutch East Indies.

Crustaceans. Here, we consider only the freshwater cymothoid species Telotha henselii (von Martens, 1869) and shrimps from the family Palaemonidae.

Telotha henselii was successively reported:

(1) As an ectoparasite on Palaemonetes argentinus from Taim, Rio Grande, Estado do Rio grande do Sul, South Brazil, by Lemos de Castro \& Gomes Corrêa (1982). The association was suggested by the authors to be of an accidental nature ('accidental infestation'). However, several male specimens were found in the branchial chamber of the shrimp.

(2) As an ectoparasite on Macrobrachium brasiliense, in rivers of the Chapada dos Guimaraes and Nioaque regions, both in Mato Grosso do Sul, Brazil, by Lemos de Castro (1985). According to the author, a great number of specimens of $M$. brasiliense was collected and many were parasitized by the male phase of Telotha henselii. On the other hand, no isopods were found parasitizing the fishes collected at the same localities. Lemos de Castro (1985) deduced, therefore, 
that perhaps the association was not accidental, but that these isopods, when young (in the male phase), utilize shrimps as intermediary hosts.

(3) As a parasite (1 male) on Macrobrachium borelli from Salado River, Santa Fe Province, Argentina, by Taberner (1993).

(4) On Macrobrachium borelli and Pseudopalaemon bouvieri by Grassini (1994), from Mandisovi Chico stream, tributary of the Uruguay Medio river, Entre Rios, Argentina. Out of the 827 shrimp examined, 101 were parasitized, mainly by 1 male, occasionally by 2 isopods. On the other hand, 13 species of Characidae, 3 Siluridae and 4 Cichlidae living in the same locality were without cymothoids. Moreover, experimental studies have proved that, when the choice between fish and shrimps is equal, Telotha henselii males prefer shrimps. Grassini (1994) concluded that the species is probably characterized by a heteroxenic life cycle; but, if that is so, the function of the shrimp stage remains to be determined!

(5) On a single specimen of Palaemonetes argentinus parasitized by 2 males, from Rio Gualeguaychu, Province of Entre Rios, Argentina, by Taberner et al. (2003).

Chondrichthyans. According to Moreira \& Sadowsky (1978), Trilles (1994) and the present study, 20 cymothoids have now been reported on chondrichthyan hosts:

(1) Nerocila acuminata Schioedte and Meinert, 1881: on sawfish (species unknown) from the Atlantic Ocean and Gulf of Mexico, Newport, Virginia, and St Mary's River, Florida (Richardson 1905, Menzies \& Frankenberg 1966), on dog fish and other unknown species from Virginia to Mexico and Bermuda (Schultz 1969) and Pristis pectinatus at Beaufort, North Carolina (Pearse 1947).

(2) Nerocila armata Dana, 1853: on sharks (species unknown) from the Pointe Padron, Congo (Brian \& Dartevelle 1949).

(3) Nerocila californica Schioedte and Meinert, 1881; synonymous with $N$. acuminata according to Bruce (1987): from Triakis semifasciata and Myliobatis sp. at San Diego, California (Schioedte \& Meinert 1881), and Taboga Island, Panama Bay, and Point Sur, National City, California (Richardson 1905, Guryanova 1936).

(4) Nerocila fluviatilis Schioedte and Meinert, 1881: 1 female on Mustelus canis from the Montevideo coast, Uruguay, South America (Cordero 1937, Trilles 1975; as $N$. orbignyi, Ringuelet 1947; as N. armata, Moreira 1973)

(5) Nerocila maculata Milne-Edwards, 1840; synonymous with $N$. orbignyi according to Bruce (1987): on Raja sp. from the Croisic vicinity, France (Chevreux 1884, as N. affinis; Trilles 1975) and $R$. alba (Dollfus and Trilles 1976).
(6) Nerocila munda Harger, 1873: on the dorsal fin of Mustelus canis ('listed as Nerocila sp. in Marine Biological Laboratory card catalogue') from Woods Hole and vicinity (Summer et al. 1911, Trilles 1975).

(7) Nerocila orbignyi (Guérin Méneville, 1829-1832): on the elephant shark Callorhynchus milii, off the Tasmanian coast (Hale 1940) and Bass strait, Frederick Henry Bay and Storm Bay on the Australian coast (Bruce 1987; several specimens female and Aegathoid), an ovigerous female (as N. macleayii) on the fins of Chimaera sp. from Warrnambool, Victoria (Hale 1926).

(8) Creniola laticauda (Schioedte and Meinert, 1881): 1 ovigerous female recorded (as Nerocila laticauda) on Raja australis from Kingston, the SE coast and Port Willunga, South Australia (Hale 1926, Trilles 1975, Bruce 1987).

(9) Anilocra elviae n. sp.: 1 female and 1 male collected on the mako shark Isurus oxyrinchus from the Gulf of Mexico, off the Port of Veracruz by Winfield et al. (2002).

(10) Anilocra physodes (L., 1758): 1 female on Squatina squatina ( $S$. angelus) from Naples, Italy (Nierstrasz 1918), and 1 male on Raja clavata from Bizerte, Tunisia (Capapé \& Pantoustier 1976), and also from Torpedo (as Anilocra mediterranea), from the Spanish Mediterranean coast (Gibert i Olivé 1919-1920).

(11) Ceratothoa collaris Schioedte et Meinert, 1883: 1 male on Raja miraletus from Tunis Bay (Trilles \& Raibaut 1973) and another on Torpedo marmorata from Tabarka, Tunisia (Capapé \& Pantoustier 1976).

(12) Ceratothoa gaudichaudii (Milne-Edwards, 1840): on Squalus fernandinus from the southern Chilean coast (Jaramillo 1977).

(13) Ceratothoa oxyrrynchaena (Koelbel, 1878): several ovigerous females on Raja asterias, R. clavata, Torpedo marmorata and Scyliorhinus stellaris from Tabarka and Bizerte, Tunisian coast (Capapé \& Pantoustier 1976).

(14) Ceratothoa parallela (Otto, 1828): 2 females and 1 male on Raja asterias and $R$. clavata from Tabarka and Bizerte (Capapé \& Pantoustier 1976). It should be noted that, according to Capapé \& Pantoustier (1976), the prevalence of $C$. collaris, C. oxyrrhynchaena and C. steindachneri on chondrichthyans is relatively low but this parasitism is not accidental or occasional.

(15) Livoneca redmanii Leach, 1818 (as L. ovalis according to Trilles 1976 and Bruce 1990): on the sawfish Pristis semisagittatus ( $P$. cuspidatus) from Massachusetts on the Atlantic coast of North America (Richardson 1905), on sawfish (species unknown) from Vineyard Sound along the entire eastern seaboard to the mouth of the Mississippi River (Miner 1950), and on sawfish Pristis sp. from Great South Bay, New York (Alperin 1966, Briggs 1970). 
(16) Livoneca sinuata Koelbel, 1878: an ovigerous female on Raja miraletus from Tunis Bay (Trilles \& Raibaut 1973).

(17) Livoneca sp. ? (as Lironeca sp. ? according to Bruce, 1982 and Livoneca sp. 12 according to Trilles, 1994): 1 female from the stomach of Callorhynchus kaianus caught at Tolo Harbour, Hong Kong (Bruce 1982).

(18) Livoneca sp. 1 (as Lironeca sp. 1 according to Sartor, 1986 and Livoneca sp. 13 according to Trilles, 1994): 1 female and 1 juvenile on Squalus cubensis from Rio de Janeiro, Brazil (Sartor 1986).

(19) Elthusa raynaudii (Milne-Edwards, 1840): as Livoneca raynaudii according to Bruce (1990) on shark (species unknown) from the Eastern Seas (Guryanova 1936) and from the stomach of the smooth-hound Mustelus from New Zealand (Hurley 1961).

(20) Aegathoa medialis Richardson, 1900: 8 specimens on Dasyatis sabina from Alligator Harbor, Florida (Pearse 1952).

Amphibians. Stadler (1972) reported that only freshwater cymothoids at the second larval stage swim freely, parasitizing various species of fishes and amphibians, before meeting the specific host.

Humans. Concerning Nerocila orbignyi (GuérinMeneville, 1829-1832) and other cymothoids from the Congo, it is worth remembering that, as Brian \& Dartevelle (1949) wrote, 'Ces Crustacés sont particulièrement féroces; ils mordent même avec vigueur la peau des baigneurs aux endroits où se trouvent de petites érosions, occasionnant des démangeaisons; mais ces morsures ne peuvent causer de dermatites'. ${ }^{1}$

\section{DISCUSSION}

Cymothoids typically infect osteichthyan fish (Brusca 1981, Trilles 1994, Bunkley-Williams \& Williams 1998). However, as reported above, some settle or collect on other organisms such as sponges, jellyfish, cephalopods, crustaceans, chondrichthyans and amphibians. It seems that such unusual associations are much more frequent with cephalopods, shrimps and, particularly, with sharks and skates. We observed that not only juveniles and males, but also females, are involved. Indeed, several females were collected from cephalopods and chondrichthyans. However, it seems that shrimps constitute a particular case, since only juveniles and males have until now been collected from these crustaceans.

The main point is, therefore, to determine, following several previous authors (Trilles 1969, Stadler 1972,

\footnotetext{
${ }^{1}$ These crustaceans are particularly ferocious, even vigorously biting the skin of bathers in places with small erosions, producing itch, but not dermatitis.
}

Capapé \& Pantoustier 1976, Lemos de Castro \& Gomes Corrêa 1982, Lemos de Castro 1985, Grassini 1994, Bello \& Mariniello 1998), whether such unusual associations are accidental, occasional or whether such unusual organisms are true potential hosts for some cymothoids. Concerning this last point, Williams \& Bunkley-Williams (1994) reported that new associations are usually begun by immature stages, but may also be initiated by adults, and these observations make them excellent subjects for discerning complex parasitological processes.

In the case of cymothoids, we think that there are 2 main possibilities: an occasional transfer from one host to another, during or after fishing, especially in the case of females; or else random migrations, perhaps quite specific in the case of Telotha henselii and shrimps, accomplished by juveniles and some swimmer males.

In such cases, but particularly in the case of a durable settlement after an unusual transfer, the way in which the parasite adapts itself to the new conditions, especially given that cymothoids feed on fish blood, is unclear. In addition, the usefulness of the intermediate host needs to be clarified with regards to the possible specific attachment of Telotha henselii to shrimps (Grassini 1994).

Acknowledgements. We thank the reviewers, Dr. Kabata and anonymous, for their time taken to carefully review our manuscript. We believe that their positive comments have substantially improved this article.

\section{LITERATURE CITED}

Alperin IM (1966) A new parasite of striped bass. N Y Fish Game J; General Notes 13(1):121-123

Avdeev VV (1977) Three new species of parasitic isopods (Flabellifera, Anilocridae) from the collection of the Laboratory of Parasitology of sea animals TINRO. Izv TINRO 101:139-144

Bello G, Mariniello L (1998) Occurrence of Livoneca sinuata (Isopoda, Cymothoidae) in the mantle cavity of Sepiola ligulata (Cephalopoda, Sepiolidae). Arch Fish Mar Res 46(1):37-42

Boone PL (1935) Crustacea: Anomura, Macrura, Euphausiacea, Isopoda, Amphipoda and Echinodermata: Asteroidea and Echinoidea. Scientific results of the world cruise of the yacht 'Alva' 1931, William K. Vanderbilt, commanding. Bull Vanderbilt Mar Mus VI:1-264

Borcea I (1933) Livoneca pontica, nov. sp., Cymothoide parasite des Aloses et Sardines de la Mer Noire. Ann Sci Univ Jassy XVII(3-4):481-505

Boscolo L (1970) Osservazioni sulla biologia e sulla pesca dell'Atherina boyeri Risso, 1810 (Osteichthyes, Atherinidae) vivente nella acque dell'Alto Adriatico. Boll Pesca Piscic Idrobiol XXV(1):61-79

Boscolo L (1977) Mothocya epimerica Costa (Isopode, Cymothoidae) parassita di Atherina boyeri Risso (Osteichthyes, Atheriniformes) nelle acque dell'Alto Adriatico. Atti Soc Ital Sci Nat Mus Civ Stor Nat Milano 118(1): 103-108 
Brian A (1912) Di un isopodo parassita dei pesci (Livoneca sinuata Koelbel). Riv Mens Pesca Idrobiol VII:97-99

Brian A, Dartevelle E (1949) Contribution à l'étude des Isopodes marines et fluviatiles du Congo. Ann Mus R Congo Belge (Zoologie, série III) 1(2):77-208

Briggs PT (1970) Records of ecto-parasitic isopods from Great South Bay, New York. N Y Fish Game J 17(1):55-57

Bruce NL (1982) On a small collection of marine isopoda (Crustacea) from Hong Kong. In: Morton BS, Tseng K (eds) Proc 1st Int Mar Biol Workshop: The Marine Flora and Fauna of Hong Kong and Southern China, Hong Kong, 1980. Hong Kong University Press, Hong Kong, p 315-324

Bruce NL (1987) Australian species of Nerocila Leach, 1818 and Creniola n. gen. (Isopoda: Cymothoidae), Crustacean parasites of marine fishes. Rec Aust Mus 39:355-412

Bruce NL (1990) The genera Catoessa, Elthusa, Enispa, Ichthyoxenus, Idusa, Livoneca and Norileca n. gen. (Isopoda, Cymothoidae), Crustacean parasites of marine fishes, with descriptions of eastern Australian species. Rec Aust Mus 42:247-300

Brusca RC (1981) A monograph of the isopode Cymothoidae (Crustacea) of the eastern Pacific. Zool J Linn Soc 73: 117-199

Bunkley-Williams L, Williams EH Jr (1998) Isopods associated with fishes: a synopsis and corrections. J Parasitol 84(5): 893-896

Capapé C, Pantoustier G (1976) Liste commentée des Isopodes parasites de Selaciens des côtes Tunisiennes. I. Côtes septentrionales, de Tabarka à Bizerte. Arch Inst Pasteur Tunis 3:197-210

Carus JV (1885) Coelenterata, Echinodermata, Vermes, Arthropoda. Prodromus fauna Mediterraneae, sive descriptio animalium Maris Mediterranei incolarum quam comparata silva rerum quatenus innotuit adiectis locis et nominibus vulgaribus eorumque auctoribus in commodum zoologorum. E Schweizerbart'sche, Stuttgart p $1-525$

Chevreux E (1884) Crustacés amphipodes et isopodes des environs du Croisic. C R Ass Fr Avanc Sci, 12ème Session (Rouen 1883), p 517-520

Cordero HE (1937) Nerocila fluviatilis y otros isopodos de las familias Cymothoidae y Bopyridae del Uruguay y del Brasil. An Mus Nac Montevideo, Sér 2a 4(12):1-11

Dollfus RP (1958) Copépodes, isopodes et helminthes parasites de céphalopodes de la Méditerranée et de l'Atlantique Européen. Faune Mar Pyrénées Orientales 1:61-72

Dollfus RP, Trilles JP (1976) A propos de la collection R.P. Dollfus, mise au point sur les cymothoadiens jusqu'à présent récoltés sur des téléostéens du Maroc et de l'Algérie. Bull Mus Hist Nat Paris (3ème Sér) 390(Zool 272):821-830

Galati-Mosella R (1920) Sulla Livoneca sinuata Koelbel, parassita di Cepola rubescens e di Atherina mocho. Monitore Zool. Ital XXXI anno (1-2):1-10

Gerstaecker A (1901) Isopoda. In: Bronn HCG (ed) Die Klassen und Ordnungen der Arthropoden wissenschaftlich dargestelt in Wort und Bild. 5 (II) Crustacea (Zweite Hälfte, Malacostraca). CF Winter'sche Verlagshandlung, Leipzig, p 8-278

Gibert i Olivé AM (1919-1920) Crustacis de Catalunya. Treb Inst Catal Hist Nat 5:9-127

Gourret P (1891) Les lemodipodes et les isopodes du Golfe de Marseille. Ann Mus Hist Nat Marseille (Zool) IV(1):1-44

Grassini CM (1994) Estudios preliminares de Telotha henselii (Custacea: Isopoda: Cymothoidae) parasito de camarones Palemonidos. Ann Mus Hist Nat Valparaiso 22:81

Gurjanova EF (1936) Beiträge zur Kenntnis der Isopoden fauna des Pazifischen Ozeans. IV. Neue Isopodenarten aus dem Japanischen und Beringmeer. Zool Anz Leipzig 114:250-265

Hale HM (1926) Review of Australian isopods of the Cymothoid group; Part II. Trans R Soc S Aust 50:201-234

Hale HM (1940) Report on the Cymothoid Isopoda obtained by the F.I.S. 'Endeavour' on the coast of Queensland, new South Wales, Victoria, Tasmania and South Australia. Trans R Soc S Aust 64:288-304

Harger O (1878) Description of new genera and species of Isopoda, from New England and adjacent regions. Am J Sci (3rd Ser) XV(89):373-379

Haswell WA (1880) On some new Australian marine Isopoda, Part I. Proc Linn Soc N S W V:470-481

Heller C (1868) Ordo Isopoda. In: Reise der Osterreichischen Fregatte Novara um die Erde in den Jahren 1857, 1858, 1859. Zoologischer Teil Zweiter Band, III Abt:130-147. Aus der Kaiserlich-Königlichen Hof- und Staatsdruckerei 1868 Commission bei Karl Gerold's Sohn, Wien

Hochberg FG (1990) Diseases of Mollusca: Cephalopoda. Diseases caused by protistans and metazoans. In: Kinne O (ed) Diseases of marine animals, Vol 3. Biologische Anstalt Helgoland, Hamburg, p 47-227

Hurley DE (1961) A checklist and key to the Crustacea Isopoda of New Zealand and the subantarctic Islands. Trans R Soc N Z (Zool) I(20):259-292

Jaramillo E (1977) Nuevos huespedes y distribution geografica de Meinertia gaudichaudii (Milne-Edwards, 1840), (Isopoda, Cymothoidae). Medio Ambiente (Seccion Extension) 3(1):132-134

Koelbel C (1878) Uber einige neue Cymothoiden. Sber Akad Wiss Wien LXXVIII:401-416

Lemos de Castro A (1985) Ectoparasitism of Telotha henselii (von Martens) (Isopoda, Cymothoidae) on Macrobrachium brasiliense (Heller) (Decapoda, Palaemonidae). Crustaceana 49(2):200-201

Lemos de Castro A, Gomes Corrêa MM (1982) Sobre un curioso caso de ectoparasitismo de Telotha henselii (von Martens) (Isopoda-Cymotoidae) em Palaemonetes argentinus Nobili (Decapoda-Palaemonidae). Bol Mus Nac Brasil (Zool) 303:1-8

Menzies RJ, Frankenberg D (1966) Handbook on the common marine isopod Crustacea of Georgia. University of Georgia Press, Athens, GA, p V-VIII and 1-93

Miner RW (1950) Field book of seashore life. GP Putnam's Sons, New York, p 440-443

Monod T (1924) Isopoda. In: Parasitologia Mauritanica. Matériaux pour la faune parasitologique en Mauritanie. Bull Com Etud Hist Sci Afr Occid Fr. Fascicule 1, 2ème Partie, p 428-445

Monod T (1933) Tanaidacea et Isopoda. In: Mission Robert Ph. Dollfus en Egypte. Mem Inst Egypte XXI:161-264

Montalenti G (1948) Note sulla sistematica e la biologia di alcuni Cimotoidi del golfo di Napoli (gen. Emetha, Meinertia, Mothocya, Anilocra, Nerocila). Arco Oceanogr Limnol Anno V I-III:26-81

Moreira PS (1973) Especie de Isopoda (Crustacea, Peracarida). Relatorio sobre a segunda pesquisa oceanografica e pesquera do Atlantico Sul entre Torres e Maldonado (Lat. $29^{\circ} \mathrm{S}-35^{\circ} \mathrm{S}$ ). Programa Rio Grande do Sul II Part I:213-229

Moreira PS, Sadowsky V (1978) An annotated bibliography of parasitic Isopoda (Crustacea) of Chondrichthyes. Bolm Inst Oceanogr S Paulo 27(2):95-152

Nierstrasz HF (1915) Die Isopoden-Sammlung im Naturhistorischen Reichs-Museum zu Leiden-I. Cymothoidae. Zool Meded Leiden I:71-108 
Nierstrasz HF (1918) VIII-alte und neue Isopoden. Zool Meded Leiden IV:103-142

Pearse AS (1947) Observations on the occurrence of certain barnacles and isopods at Beaufort, North Carolina. J Wash Acad Sci 37:325-328

Pearse AS (1952) Parasitic crustaceans from Alligator Harbor, Florida. Q J Fla Acad Sci 15(4):187-243

Penso G (1939) Nuovo parassita e nuova parassitosi del 'Gadus potassou'. Corr Pesca Anno 12:19:1

Richardson H (1905) A monograph on the isopods of North America. Bull US Natl Mus 54:1-727

Richardson H (1910) Marine isopods collected in the Philippines by the US fisheries steamer Albatross in 1907-8. Department of Commerce and Labor Bureau of Fisheries 736:1-44

Ringuelet R (1947) Anotaciones sobre copepodos e isopodos parasitos de peces. Notas Mus La Plata (Zool) 12(98): 93-107

Rokicki J (1984) Parasitic isopods of the N. W. African Shelf in connection with their occurrence in fish. Zedzyty Naukowe. Rozp Monogr 50:1-222 (in Polish)

Sartor SM (1986) Incidencia de isopodos parasitas (Cymothoidae) em peixes da plataforma continental Brasileira. Bolm Inst Oceanogr S Paulo 34(unico):1-12

Schioedte JC, Meinert F (1881) Symbolae ad monographiam Cymothoarum Crustaceorum Isopodum familiae. II. Anilocridae. Naturhist Tidsskr Ser III, XIII:1-166

Schioedte JC, Meinert F (1884) Symbolae ad monographiam Cymothoarum Crustaceorum Isopodum familiae. IV. Cymothoidae. TRIB. II. Cymothoinae. TRIB. III. Livonecinae. Naturhist Tidsskr Ser III, XIV:221-454

Schultz GA (1969) The marine isopod crustaceans. The pictured key. Nature series. WMC Brown Company Publishers, Dubuque, p 1-359

Stadler T (1972) Braga bachmanni, nuevo ectoparasito de Ancistrus cirrosus (Crustacea, Cymothoidae) en pisces Loricariidae. Neotropica 18(57):141-145

Summer FG, Osburn RC, Cole JL (1911) A biological survey of the waters of Woods Hole and vicinity. Part II: Section IIIA catalogue of the Larine fauna. Bull Bur Fish Wash XXXI:549-794

Szidat L (1955) Beiträge zur Kenntnis der Reliktfauna des La Plata Stromsystems. Arch Hydrobiol 51(2):209-269

Taberner R (1993) A revision of the genus Telotha (Isopoda: Cymothoidae). Physis B Aires Secc B 48(114-115), 1990: 25-37

Taberner R, Volonterio O, Ponce de Leon R (2003) Description of the pulli of Telotha henselii (von Martens, 1869) (Isopoda, Cymothoidae), with new hosts and locality records from Uruguay and Argentina. Crustaceana 76(1):27-37

Trilles JP (1962) Remarques morphologiques et biologiques sur les isopodes Cymothoidae 'parasites de poissons' de l'étang de Thau. Nat Sér Zool III:101-124

Trilles JP (1968) Recherches sur les isopodes Cymothoidae

Editorial responsibility: Wolfgang Körting,

Hannover, Germany des côtes Françaises. Thesis Montpellier, no. enregistrement CNRS AO 2305. Vol I: Bionomie et parasitisme and Vol 2: Biologie générale et sexualité, p 1-793. Vol 3: Systématique et faunistique. University of Montpellier, p 1-181

Trilles JP (1969) Recherches sur les isopodes 'Cymothoidae' des côtes françaises. Aperçu général et comparatif sur la bionomie et la sexualité de ces Crustacés. Bull Soc Zool Fr 94(3):433-445

Trilles JP (1972) Les Cymothoidae (Isopoda, Flabellifera) du Muséum National d'Histoire naturelle de Paris. Etude critique accompagnée de précisions en particulier sur la répartition géographique et l'écologie des différentes espèces représentées. I-Les Ceratothoinae Schioedte et Meinert, 1883. Bull Mus Hist Nat Paris 3ème Sér 91(Zool 70):1231-1268

Trilles JP (1975) Les Cymothoidae (Isopoda, Flabellifera) des collections du Muséum national d'Histoire naturelle de Paris. III. Les Cymothoidae Schioedte et Meinert, 1884. Genre Cymothoa Fabricius, 1787. Bull Mus Hist Nat Paris 3ème Sér 318(Zool 225):977-993

Trilles JP (1976) Les Cymothoidae (Isopoda, Flabellifera) des côtes françaises. III. Les Lironecinae Schioedte et Meinert, 1884. Bull Mus Hist Nat Paris, 3ème Sér 390 (Zool 272): $801-820$

Trilles JP (1977) Les Cymothoidae (Isopoda, Flabellifera; parasites de poissons) du Rijksmuseum van Natuurlijke Historie de Leiden. Méditerranée et Atlantique. Zool Meded Leiden 52(2):7-17

Trilles JP (1994) Les Cymothoidae (Crustacea, Isopoda) du monde. Prodrome pour une faune. Stud Mar 21/22(1-2) (1991):5-288

Trilles JP, Raibaut A (1973) Sur les Cymothoidae (Isopoda, Flabellifera) parasites de poissons marins de Tunisie (2ème note). Bull Mus Hist Nat Paris 3ème Sér 114(Zool 88):273-281

Trilles JP, Radujkovic BM, Romestand B (1989) Parasites de poissons marins du Montenegro: isopodes. In: Radujkovic BM, Raibaut A (eds) Faune des parasites des poissons marins des côtes du Montenegro (Adriatique sud). Acta Adriat 30(1-2):279-306

Vasiliu GD (1932) Livoneca sinuata Koelb. ein Kiemen parasit des fisches Atherina hepsetus L. Publnile Soc Nat Rom 11: $177-180$

Vasiliu GD, Carausu A (1948) Contribution à l'étude des Cymothoidae (Isopodes parasites) de la Mer Noire. Ann Sci Univ Jassy XXXV:175-186

Williams EH, Bunkley-Williams L (1994) Four cases of unusual crustacean-fish associations and comments on parasitic processes. J Aquat Anim Health 6:202-208

Winfield I, Alvarez F, Ortiz M (2002) A new species of Anilocra (Crustacea: Isopoda: Cymothoidae), ectoparasitic on the mako shark Isurus oxyrinchus. Proc Biol Soc Wash 115(1):148-152

Submitted: March 20, 2004; Accepted: June 26, 2004

Proofs received from author(s): October 8, 2004 